\title{
Justification of Reward of Capital in the Capitalist Economic System
}

\author{
Dr.Farooq Aziz, Syed Muhammad Fahim, Waqar Ud Din Usmani, \\ Muhammad Rizwan \\ Department of Business Administration Assistant Professor Federal Urdu University Karachi-Pakistan \\ Department of Management Sciences Assistant Professor DHA Suffa University Karachi-Pakistan \\ Department of Business Administration Assistant Professor Institute of Business Technology Karachi-Pakistan \\ Department of Business Administration Lecturer Dow University of Health Sciences Karachi-Pakistan
}

\begin{abstract}
In the modern capitalist system reward of capital (property) is considered as lawful. Any income which came from this source e.g. rent \& interest is not the result of labour of capitalist but the capital itself earned this income for him. It means it is an unearned income from capitalist point of view. This situation is quite same as in the case of any illegal income e.g. cheating, fraud, illegal commission and many other sources like these. The persons involved in all such activities also get unearned income, hence from receivers point of view basically there is no difference between these two, and no logical reason is left to condemn the latter. This problem may be solved if labour is considered as the only standard of remuneration.

$\begin{array}{lllll}\text { JEL Classification } & D-24 & J-32 & J-33 & D 31\end{array}$

Key words: $\quad$ Capital; labour; Reward; Illegal income.
\end{abstract}

\section{Introduction:}

The modern capitalist economic system is based on the concept of four factors of production i.e. land, labour, capital and entrepreneur. These factors got reward in the form of rent, wages, interest and profit/ loss respectively against their services. But there are some logical problems related to the base of their remuneration. This system adopts two different standards for the reward of capital and labour (Aziz, Farooq; Abbas, Hussain: 2011). With that, some other problems are also their. One problem is relating to the deep resemblance between the income from capital and all illegal sources of income, which raise's serious objection on the validity of income from capital. This situation also creates a question that is any reasonable standard of remuneration for all factors of production is possible?

In order to highlight the above mentioned problem and its possible solution, this paper is divided in five parts. Their introduction is as follows:

Section two deals with the nature of capital and one important feature of income from capital.

In section three illegal sources of income and their resemblance with income from capital is discussed.

Labour as a factor of production, as a standard of reward is described in the fourth section.

Answers of some possible objections are given in the fifth \& last section of this paper.

\section{Capital: As a Factor of Production}

In modern economics capital is considered as a factor of production. It may be defined as financial assets or the financial value of the assets such as cash, machine, equipment, plant and building etc. (www.investopedia.com/terms/capital.asp). Definitely capital is a very vague term and its specific definition depends upon the context in which it is used. In this paper it is defined as any wealth which is used for production of further wealth. In this context almost all assets fall in this category because they are used for generation of income or wealth. For example all non current assets can be given on rent. With the help of cash, shares, bounds and marketable securities etc., are purchased which also generate income in the form of interest. Cash may be given for debt to earn interest. Hence capital means all those assets which generate income in one form or other. This is the reason that this term may be defined as the factor of production which generated income. (www.thefreedictionary.com/capital).

The important point is that, this income is not the result of labour of capitalist, but it is the result of services of different assets owned by him. In this way this income may be termed as Unearned Income, or that income which is the result of services of capital and will not be the result of labour. 


\section{Illegal Sources of income $\&$ their resemblance with income from Capital}

Illegal sources of income are those sources of income which are prohibited by the law throughout the world, e.g. cheating, fraud, black marketing, illegal commission and all those activities which are not allowed under the law. At here point of consideration is that, in all of these sources, the persons who involved in these activities also get unearned income, because the income so received is also not the result of their dint of labour. From legal point of view all of them are restricted, whereas the nature of income is quite same as in the case of income from capital. Hence no logical reason is left to consider them unlawful, because by nature there is not any difference between these two. In both cases receiver received that income which is not the result of his labour but it is easy money. This situation definitely raise the question to reconcile this contrast, or to set any common standard on the basis of which, this problem may be solved. Labour as a factor of production is the only solution of this problem. But before the analysis of labour as a standard in this regards, it is necessary to define labour and keep some of its basic characteristics in mind.

\section{Labour as the Factor of Production}

Whereas the labour is concerned it may be defined as any productivity especially for the purpose of economic gain / reward. (www.freedictionary.com/labour). In the other word it may be termed as any valuable service rendered by human being for the production of wealth (www.answers.com/topic/labour-1). In these definitions following points are important:

4.1.1 According to them each and every type of physical and (or) mental exercise is included in labour. It may be in the form of a plumber, truck driver, engineer, justice or any other profession.

4.1.2 It is necessary for any activity which is included in labour, that it should be productive or valuable. In the other words only those activities will be considered as labour which provide more or less benefit in any form to an individual, group of persons, to the nation or to the mankind as a whole. Any destructive, harmful or miserable activity cannot be included in labour.

4.1.3 The main purpose of all such type of activities or exercises is to get reward which is normally in the form of wages / salaries, commission and fees etc. At here two basic characteristics of labour as a factor of production should be kept in mind. First labour is a basic factor of production and the second is labourer cannot work without his labour. His performance is always a result of his mental and physical exertion; both cannot be separated from each other (www.guesspapers.net/1233/characteristic-of-labour). In the other words, proxy in any form is not allowed in this case except some exceptions. On the other hand proxy is allowed in the case of capitalist, he does not work but earns through his capital. Whereas it is an open contrast of capitalist system. Prevailing system is not ready to pay a single dollar to any worker without his productive activity. In this case each and every dollar in the form of reward of labour is the result of his dint of labour and there is not any concept of unearned income in this regard. Labour lives just on the basic of earned income. This is the basic difference between the income from capital and income from labour.

\subsection{Labour as the standard of reward.}

In the above discussion it is proved that income from capital (Property) is basically an unearned income, like any income from any illegal source. Hence any legitimate base is not left for the income from capital. There may be an impossible option that income from all illegal sources should be declared as lawful to justify the income from capital. Definitely it is not possible in any case. Hence the only choice is left hat labour should be consider as the only standard of remuneration. It is due to the solid fact that production process cannot be done without labour, it is the only active factor of production.

The same case is with entrepreneur, it cannot be treated as a separate of factor of production, and it is just a form of labour not more than that. The reason it that, those functions due to which separate identity is given to him i.e. organizing, management and taking of risk (Arthur 2003) these functions are not just restricted to entrepreneur only, but these functions are performed by all human being throughout the world many times in their life. Hence these are quite common functions and entrepreneur do not have any distinction in this regard. It can be said that entrepreneur is also a form of labour not more than that.

\section{Is it a Socialist Solution?}

At here an immediate objection may arise that, it is a socialist model or at least deeply inspired from it. This objection is not correct, because there is not any match between socialism and above mentioned hypothesis. The basic structure of socialism was on the negation of concept of private ownership (Ismail 1989). Whereas the above mentioned hypothesis is based on the dignity of institution of private ownership. Hence this concept is not based on socialist philosophy. It is an effort to highlight the contradiction in prevailing capitalist economic system by accepting almost all of its basic principles. The basic principles of capitalist system e.g. recognition of institution of private ownership, market economy etc., are universal truths and will remains same 
till the Day of Judgment. Hence these principles cannot be challenged but the contradiction should be removed. Labour may be a possible solution of above mentioned contradiction.

\section{Conclusion}

Like every system present capitalist economic system has some contradictions. One main contradiction is that, income from capital and all illegal sources has a common characteristic that, in both cases the income is not the result of labour but it is a form of unearned income from receiver's point of view. Hence no logical reason is left to restrict all illegal sources of income, because by nature both of these sources are same. The only solution of this contradiction is that, labour should be treated as the standard of remuneration, it is the only choice in this regard.

\section{Reference}

[1]. Arthur, Sulliven, Sheffrin, Steven, M., (2003) Economics: Principles in Action, 4

[2]. Aziz, Farooq; Abbas, Hussain; Aqil, M., Sammad, Abdul; 2001Double Standard of Remuneration of Different Factors of Production in a Capitalist Economy. European Journal of Social Sciences (23) 2, 318-322

[3]. Ismail, S.M; (1989) Critical Analysis of Capitalism, Socialism and Islamic Economic Order. 311

\section{Websites}

(www.investopedia.com/terms/capital.asp).

(www.thefreedictionary.com/capital).

(www.thefreedictionary.com/labour).

(www.answers.com/topic/labour-1)

(www.guesspaper.net/1233/characteristic-of-labour) 